\begin{tabular}{|c|c|c|}
\hline 報 & 文 & Original \\
\hline
\end{tabular}

\title{
リンパ管の機能低下が引き起こすしわ形成 メカニズムの解明とその薬浏開発*1
}

\author{
加治屋健太朗*2 4, 河合江理子*2, 岸 本 治 郎*2, \\ マイケル・デトマー*3,4
}

株式会社資生堂 リサーチセンター*2, スイス連邦工科大学薬学部*3,

$\mathrm{CBRC}(\mathrm{MGH} / \text { ハーバード皮膚科学研究所 })^{* 4}$

\begin{abstract}
リンパの流れが滞るとむくみが起こることが知られている。皮膚のリンパ管の機能は，不要になっ た水分や老廃物の排出だけでなく, ウイルスなどの感染からの防御反応として重要な役割を果たして いると考えられてきた。一方で, 皮膚の老化への関わりとその分子メカニズムについては未知であっ た。われわれは, 皮膚老化の引き金になる紫外線によって皮膚のリンパ管が顕著に拡張し, その回収 機能が低下していることを見出した。また, リンパ管の回収機能の低下は, リンパ管から回収される べき炎症性細胞を真皮内に留めることになり, 炎症状態を長引かせて弾性纎維の分解などの皮膚のダ メージにつながることを示した。さらに，このリンパ管機能の低下には，表皮で産生されるリンパ管 活性化因子 VEGFC の発現低下が関与していることを見出した。これらより, VEGFC の発現低下 がリンパ管の機能低下を引き起こしていることが示唆された。そこで, 表皮でVEGFC の発現を促 進する薬剤を 800 種以上の化合物と生薬ライブラリーのなかからスクリーニングして化合物 MACC にその効果を見出した。MACC はリンパ管に働きかけて紫外線による皮膚ダメージを回復させると 考えられる。
\end{abstract}

\section{1. 緒言}

長期の紫外線,特に UVB (290〜320 nm) の暴露によっ て，皮虐にはしわ形成，マトリックス高分子の分解，線 維症など一連の老化現象が引き起こされることが知られ ている。また, 単回のUVB 照射は, 表皮の肥厚, 紅斑, 血管透過性の元進, そして浮腫形成などを引き起こすこ とが知られている1 ${ }^{1)}$ が，長期の紫外線によっておこる 皮膚の老徵は, 単回の紫外線暴露でおこる皮虐内変化が 引き金になり蓄積された変化であると考えられる。実 際，単回のUVBの暴露にともなって皮膚の毛細血管は

${ }^{* 1}$ 2009.1. 30 受付, 2009.4. 14 採用

*22 $224-8558$ 横浜市都筑区早渕 2-2-1 : 2-2-1, Hayabuchi, Tsuzuki-ku, Yokohama 224-8558, Japan

* 3 Wofgang-Pauli-Strasse10, チューリッヒ, 8093, スイス: Wofgang-Pauli-Strasse10, Zurich, 8093, Switzerland

*4 13th Street, チャールズタウン, MA, 02129, アメリカ： 13th Street, Charlestown, MA, 02129, USA
新生するが3)，この新生した血管から漏出する炎症性細 胞の一種, 好中球がマトリックスを分解することがわか $り^{3)}$, 単回の紫外線暴露による皮膚内変化の蓄積が老化 現象につながることが示された。一方で，紫外線暴露に よる皮膚リンパ管の機能の変化に関しては全くわかって いなかった。リンパ管は, 皮膚では真皮に存在し, 真皮 内の余分な水分やタンパクなどの不要な因子を回収する のに重要な役割を果たしていると考えられている。ま た, 免疫細胞の輸送を介して免疫反応にも関与するとい われている。最近の研究で, リンパ管内皮細胞の增殖・ 遊走を促進して活性化する因子として VEGFC が見出さ れ，リンパ管に特異的に発現する受容体 VEGFR-3を介 してその効果を発揮することが示された4)。さらに， VEGFR-3を介したシグナル伝達の中和抗体を皮膚で高 発現させることで真皮に浮腫が起こることがわかり, 皮 膚においてはVEGFCが重要な役割を果たすことが示さ れた5)。われわれはこれまでに, VEGFR-3のシグナルを 中和抗体により阻害することで紫外線 UVBによる皮虐 
ダメージが遅延する知見を得た6)。加えて, 恒常的に 紫外線を浴びた光老化皮膚でリンパ管の数が減少するこ と7)から,リンパ管の機能が老化, 特に光老化に重要な 役割を果たすのではないかと考えた。そこで, 本研究で は, リンパ管の機能が紫外線による皮膚老化のメカニズ ムに果たす役割とともにその分子制御機構の解明を目的 とした。

\section{2. 実 験 方 法}

\section{1. ヒト皮膚組織サンプル}

単回の紫外線照射実験では, 5 人の健常人から UVB を 2 MED 照射した（Dermaray M-DMR 100 ; Toshiba, Tokyo）臂部皮膚㧍よびコントロール皮膚を採取した。ま た，30歳以下のしわのない目じり皮膚および光老化し た 60 歳以上の皮虐（各 5 例）も採取した。採取にあたっ ては，資生堂倫理委員会によるガイドラインに従った。

\section{2. 免疫組織化学染色および皮膚リンパ管の 定量解析}

免疫組織染色は，冷アセトンで固定したヒト皮膚組織 の $6 \mu \mathrm{m}$ のパラフィン切片を用いた。1 次抗体は, podoplanin（リンパ管) (D2-40 ; Signet Laboratories, Dedham, MA), CD68（マクロファージ）（Santa Cruz Biotechnology, Santa Cruz, CA), VEGFC (Zymed, South San Francisco, CA）を用い，各 1 次抗体の作製した動物種に対応す る HRP 標識の 2 次抗体 (Dako, Tokyo) を用い DAB 発 色させた。各免疫組織染色の画像は, オリンパスの AX80T顕微鏡および DP control digital camera を用いて 写真撮影し, リンパ管の定量解析はWinRoof 4 (MitaniCorp, Fukui）ソフトウェアを用いて解析を行った。

\section{3. 細胞培養および VEGFC 誘導薬剈の}

\section{スクリーニング}

表皮細胞由来の $\mathrm{HaCaT}$ 細胞は，10\% FBS を添加した Dulbecco's modified Eagle's medium (DMEM) で培養し た。 $\mathrm{HaCaT}$ 細胞に, $20 \mathrm{~mJ} / \mathrm{cm}^{2}$ の UVB を照射（TOREX FL205-E-30-DMR ; Toshiba) した。UVB 照射後，0，4， $8 ， 12 ， 24$ ，そして 48 時間後の $\mathrm{HaCaT}$ 細胞の RNA を Trizol（Invitrogen, Carlsland, CA）を用いて回収し，RQ1 RNase-free DNase（Promega, Madison, WI）を用いてゲノ ムDNAを除いた。VEGFCの発現解析は, ABI Prism 7000 Sequence System (Applied Biosystems, Foster City, CA）を用いて定量的 RT-PCRを行い，Applied Biosystems でデザインされた TaqMan プローブを用いて反応 を行った。また, VEGFCタンパクの産生量は, 薬剤添 加 2 日後の培地を採取して VEGFC 用の ELISA (R\&D Systems, Minneapolis, MN) を用いて解析した。ヒト皮膚
由来のリンパ管内皮細胞 $(\text { LEC })^{8)}$ は，添加因子キット を含んだEBM-2（Cambrex；Verviers, Belgium）で培養 した。真皮ゲル中にLECを含んだ皮膚の 3 次元培養法 を確立し, 最大 15 日間培養して薬剤の有無での LEC の 管腔形成能を評価した。

\section{3. 結果}

\section{1. 紫外線照射後の皮膚リンパ管の機能低下}

紫外線の皮膚リンパ管機能への関与を解析するため に，健常人ボランティアの慰部皮膚に $2 \mathrm{MED}$ の紫外線 UVB を照射し，照射 2 日後に組織変化を解析した。ま ず，リンパ管のマーカーであるポドプラニンの免疫染色 を施した。その結果，正常皮膚では真皮中に存在するリ ンパ管は，平たい線状の構造が見て取れたが，紫外線を 照射することで顕著に拡張していた（Fig.-1）。画像解 析ソフトを用いて定量的な解析を行った結果, リンパ管 の平均的な大きさは紫外線照射後に, 約 2.5 倍以上に増 大していた。一方で, リンパ管の密度は, 紫外線照射後 に変わらなかった。

\section{2. リンパ管の回収機能低下による皮膚ダメージ}

リンパ管の回収機能の低下が，紫外線による皮膚ダ メージにどのようにつながるかを解析するために，われ われはリンパ管の重要な機能の一つである炎症性細胞の 回収に着目して研究を行った。炎症性細胞の一つである マクロファージのマーカー, CD68の免疫組織染色を 行った結果, 紫外線照射 2 日後にリンパ管が拡張してい た皮虐ではマクロファージの真皮内への浸潤が顕著に増 加していた (Fig.-2)。

\section{3. 紫外線照射後のリンパ管活性化因子 VEGFC の発現低下}

これまでに，リンパ管活性化因子 VEGFC が皮膚のリ ンパ管機能に重要な役割を果たしていることが示されて いる6)。そこで，リンパ管活性化因子 VEGFC の紫外線 照射後の発現変化を精査に解析した。VEGFC の免疫染 色を施した結果，正常皮虐ではVEGFC は表皮の全層に 発現しているのに対して，紫外線を照射した皮膚では， 表皮，特に基底層でその発現が顕著に減少していた。さ らに，VEGFCの紫外線照射後の発現を精査に解析する ために，表皮由来の細胞である $\mathrm{HaCaT}$ 細胞に UVB を照 射して, VEGFCの発現変化を解析した。その結果, 紫 外線照射 4 時間後にVEGFC の発現は顕著に減少を始 め, 8 時間後に VEGFC の発現は最も減少した。また, UVB 照射後 48 時間後でも VEGFC の発現は照射前まで 戻らなかった (Fig.-3)。 


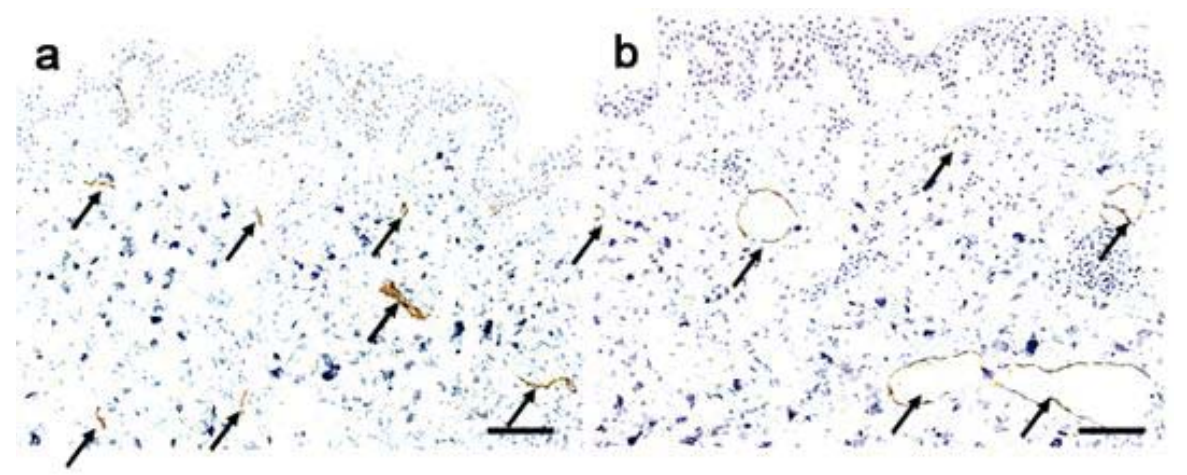

Fig. -1 The enlargement of lymphatic vessels in the UVB-irradiated skin.

Immunohistochemistry for a lymphatic-specific marker, podoplanin demonstrated that enlarged lymphatic vessels were found in the UVB-irradiated skin (b) as compared to non-irradiated skin (a). Arrows show lymphatic vessels. Scale bars $=100 \mu \mathrm{m}$.

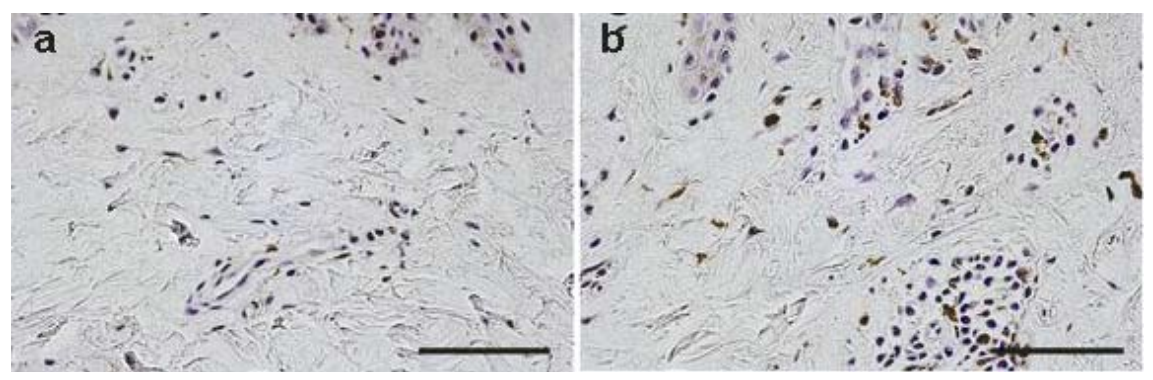

Fig.-2 Macrophage infiltration was found in the dermis of UVB-irradiated skin. Immunohistochemistry for CD68 in brown demonstrated that no of few macrophages in the dermis of normal skin (a), whereas the number of infiltrated macrophages was increased in the UVB-irradiated skin (b). Scale bars $=100 \mu \mathrm{m}$.

\subsection{MACC は VEGFC の発現を誘導して リンパ管の機能を促進する}

VEGFC の発現を促進する薬剤を探索するために，表 皮由来の $\mathrm{HaCaT}$ 細胞に約 500 種の化合物と約 250 種の 生薬を添加し, それらの VEGFC 産生に与える効果を解 析した。VEGFCは分泌型のタンパク質であるので, 薬 剤を添加した 2 日後の培養上清を回収して ELISAを用 いて VEGFCのタンパク濃度を測定した。それらの薬剤 のなかで, MACC (N-methyl-trans-4-aminomethylcyclohexanecarboxamide hydrochloride）は, VEGFC の発現を濃度 依存的に顕著に増加させた (Fig.-4)。次に, MACCに よるVEGFC の発現促進効果が皮膚リンパ管の機能を促 進するかどうかを解析するために, リンパ管内皮細胞を 真皮内に含有する 3 次元皮膚モデルを作製し, MACC の効果を解析した。3 次元皮虐モデルを回収してリンパ 管の免疫組織染色を施した結果, MACC はリンパ管の 管腔形成を有意に促進することが明らかになった（Fig.5)。
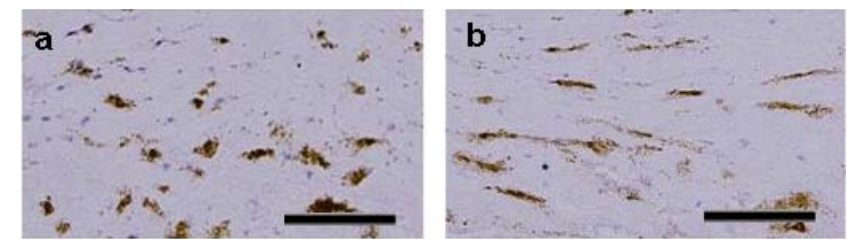

Fig. -5 MACC promoted the cord-formation of lymphatic endothelial cells in the skin equivalent model.

Immunohistochemistry for podoplanin (brown) revealed the cord-like structure of lymphatic endothelial cells in the dermis treated with MACC (b) as compared to the control model. Scale bars $=100 \mu \mathrm{m}$.

\section{4. 考}

察

長期のUVB の暴露によって, 皮膚にはしわ形成, マ トリックス高分子の分解など一連の老化現象が引き起こ されることが知られているが'1,2), 長期の紫外線暴露に よっておこる皮膚の老徵は, 単回の紫外線暴露でおこる 皮膚内変化の蓄積によって引き起こされると考えられ 


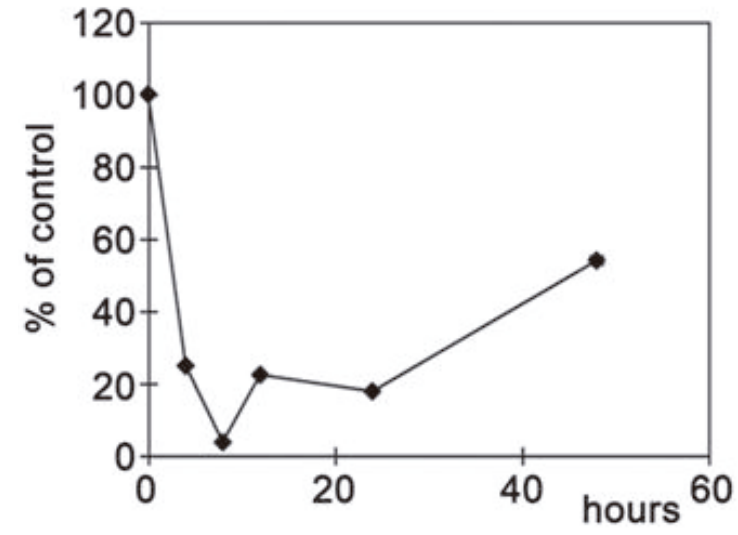

Fig.-3 The downregulation of VEGFC expression in HaCaT keratinocytes after an acute UVB irradiation.

る。実際，単回のUVB の暴露にともなう皮虐毛細血管 の新生が皮膚中に炎症を誘導して弾性繊維の一つである エラスチンを分解することがわかり ${ }^{3)}$, 単回の紫外線暴 露による皮膚内変化の蓄積が老化現象につながることが 示された。今回, 新たに単回の紫外線の照射にともない, 皮膚リンパ管が顕著に拡張することを見出した。最近わ れわれの研究で，紫外線によって拡張したリンパ管は漏 れやすく，透過性が充進していて，リンパ管の回収機能 が低下していることを見出している9)。リンパ管の拡張 は, 紫外線による血管透過性の光進の結果, 真皮内の余 分な水分・タンパク質の増加によって引き起こされると 考えられてきたが，新たにリンパ管自身の機能低下も寄 与していることがわかった。さらに, リンパ管の回収機 能の低下は，水分や老廃物だけでなく，炎症性細胞であ るマクロファージの回収も遅らせて炎症を長引かせるこ とを見出した。マクロファージは, MMP-12 と呼ばれる エラスチン分解酵素 (エラスターゼ) を含有しているこ とが一般的に知られている10)。エラスターゼは, エラス チンなどの真皮マトリックス高分子の分解に直接的に寄 与している。以上より, 紫外線照射後のリンパ管の回収 機能の低下は，エラスターゼをもつ細胞を真皮内に留ま らせた結果，エラスチンなどの真皮のマトリックス高分 子の分解を促し, ひいてはしわ形成につながることが示 唆された。

次に, 紫外線によるリンパ管の機能低下の分子メカニ ズムを解析した。これまでに, 皮膚のリンパ管の機能に は，表皮から産生されるリンパ管活性化因子 VEGFC が 重要な役割を果たしていることが示されている。そこ で, 紫外線照射後の皮膚で VEGFC の発現を解析した結 果, VEGFC の発現は顕著に減少していることが明らか になった。さらに, 表皮細胞に紫外線を照射して詳細に

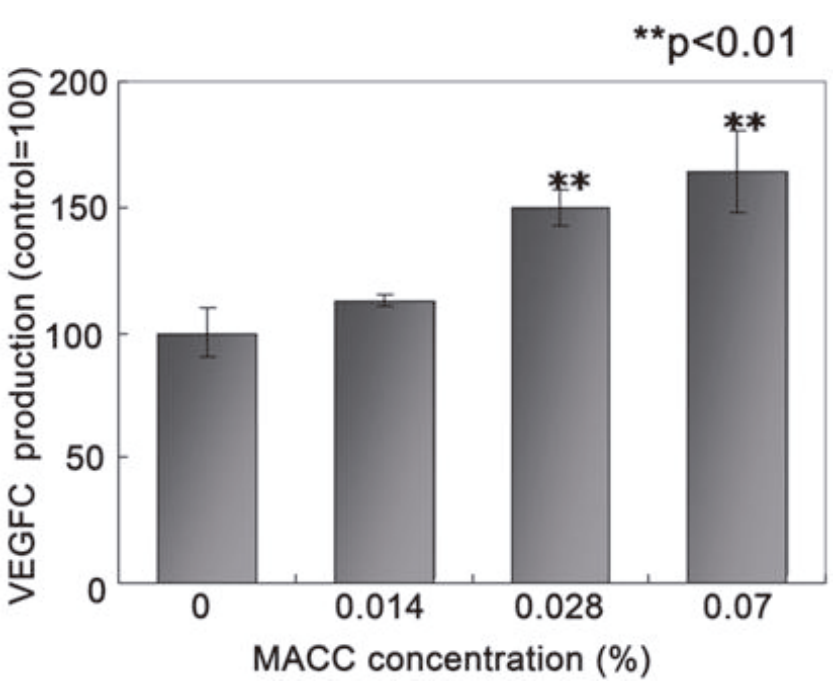

Fig. -4 The dose-dependent induction of VEGFC protein by MACC.

VEGFC の発現変化を経時的に解析した結果からも, VEGFC の発現減少が明らかになった。これらの結果か ら, 紫外線は表皮の VEGFC の発現を減少させてリンパ 管機能を低下させ，皮膚ダメージを蓄積させることが明 らかになった。リンパ管活性化因子 VEGFC の機能を特 異的に阻害すると, 紫外線による皮虐ダメージが続くこ とも今回の結果を支持する理由の一つである6)。本研究 成果から，VEGFCの発現を上昇させることでリンパ管 の機能を促進することが, 紫外線にともなう皮膚ダメー ジ，ひいては光老化によるしわ形成を緩和する実現可能 な方法であると考えられた。そこで，合計 700 種以上の 生薬挍よび化合物ライブラリーを用いて表皮で VEGFC を促進する薬剤をスクリーニングした結果，MACCに 強い活性を見出した。また，3 次元皮膚モデルを用いた 検討から，MACCがVEGFCの発現を表皮細胞で誘導し て、リンパ管の機能を促進していることが示された。リ ンパ管活性化因子 VEGFC の産生を促進する薬剤はこれ までに全く見出されていない。MACCは，リンパ管に 分子レベルで作用して機能を促進する初めての化合物で ある。

\section{5. 結論}

われわれは，初めて皮膚のリンパ管が，紫外線による 皮膚のダメージに重要な役割を果たしていることを示 し，特に紫外線照射後の表皮で産生されるリンパ管活性 化因子 VEGFC の発現減少が，リンパ管の回収機能を低 下させることを明らかにした。リンパ管の回収機能の低 下は, 炎症性細胞の回収を遅延させた結果, 真皮内に皮 膚ダメージが蓄積し、ひいてはそれが皮膚の光老化につ 
ながることが示唆された。本研究でわれわれが見出した MACC は, VEGFC の発現を上昇させ，リンパ管の機能 を促進する初めての薬剤である。MACCは, リンパ管 を基点とした全く新規でしかも効果的な皮膚老化を抑制 する方法を提供すると考えられる。

\section{引用文献}

1) A.M. Kligman, Drugs, 38 (1), 1-8 (1989)

2) N.H. Cox, B.L. Diffey, P.M. Farr, Br. J. Dermatol., 126 (4), 315-319 (1992)

3) K. Yano, K. Kadoya, K. Kajiya, Y.K. Hong, M. Detmar, Br. J. Dermatol., 152（1）, 115-121（2005）

4) L. Jussila, K.Alitalo, Physiol. Rev., 82 (3), 673-700 (2002)

5) T. Makinen, L. Jussila, T. Veikkola, T. Karpanen, M.I. Ket- tunen, K.J. Pulkkanen, R. Kauppinen, D.G. Jackson, H. Kubo, S. Nishikawa, S. Yla-herttuala, K. Alitalo, Nat. Med., 7 (2), 199-205 (2001)

6) K. Kajiya, M. Detmar, J. Investig. Dermatol., 126 (4), 919921 (2006)

7) K. Kajiya, R. Kunstfeld, M. Detmar, J.H. Chung, J. Dermatol. Sci., 47 (3), 241-243 (2007)

8) K. Kajiya, S. Hirakawa, B. Ma, I. Drinnenberg, M. Detmar, EMBO J., 24 (16), 2885-2895 (2005)

9) K. Kajiya, S. Hirakawa, M. Detmar, Am. J. Pathol., 169(4), 1496-1503 (2006)

10) U. Saarialho-Kere, E. Kerkela, L. Jeskanen, T. Hasan, R. Pierce, B. Starcher, R. Raudasoja, A. Ranki, A. Oikarinen, M. Vaalamo, J. Investig Dermatol., 113 (4), 664-672 (1999)

\title{
A Novel Mechanism of Cutaneous Photo-Aging Mediated by the Impairment of Lymphatic Function and the Protective Role of a Lymphatic-promoting Compound*1
}

\author{
Kentaro Kajiya $^{* 2-4}$, Eriko Kawai ${ }^{* 2}$, Jiro Kishimoto ${ }^{* 2}$, Michael Detmar *3,4 \\ Shiseido Research Center*2, \\ Institute of Pharmaceutical Sciences, Swiss Federal Institute of Technology *3, \\ Cutaneous Biology Research Center, MGH/Harvard Medical School ${ }^{* 4}$
}

The lymphatic system plays an important role in the maintenance of tissue fluid homeostasis and the afferent phase of immune response. However, the role of the lymphatic system in mediation of aging and its molecular mechanism have been totally unknown. Here we have identified, for the first time, the importance of the cutaneous lymphatic system in the process of ultraviolet (UV) B-induced skin-damage. UVB induced the prominent enlargement of lymphatic vessels which were leaky and hyperpermeable, suggesting that the function of enlarged lymphatic vessels induced by UVB was impaired. Moreover, impaired lymphatic function could cause prolonged inflammation with retained macrophages in the dermis, eventually leading to wrinkle formation. A potent lymphangiogenesis factor, VEGFC was downregulated after UVB irradiation in vitro as well as in vivo, suggesting that the impairment of lymphatic function was triggered by VEGFC downregulation. MACC, which was found to be a novel VEGFC-inducing compound in keratinocytes, has a strong potential to prevent UVB-induced skin damage/wrinkle formation by promoting lymphatic vessel growth and function.

Key words : lymphatic, VEGFC, UV, aging 